\title{
Phenolic Content and Antioxidant, Antibacterial Activities of Ethanolic Extract From Lemon Balm and Oregano Plants
}

\author{
Rami Ali Taqi* \\ Received 18, September, 2012 \\ Accepted 18, March, 2013
}

\begin{abstract}
:
The antioxidant and antibacterial activities of ethanolic extract and phenolic compounds extract of Lemon balm (Melissa officinalis) and Oregano (Oreganum vulgare) plants were studied; the phenolic content and the relationship between these compounds and the above activities were also investigated.

The results showed that the Lemon balm had the highest phenolic content $(56.5 \% \mathrm{mg} \backslash \mathrm{g}$ ) and the phenolic content of Oregano was twice lower than Lemon balm. Lemon balm has the highest antioxidant activity which causes lipid peroxidation inhibition activity of linoleic acid (90.5\%), this activity was more than $\alpha$ tocopherole antioxidant activity $(79.3 \%)$. It was found that the main source of antioxidant activity of these plants was belonging to phenolic compounds and the results proved the strong relationship between antioxidant activity and phenolic content.
\end{abstract}

The ethanolic extract of Lemon balm was exhibited strong antibacterial activity ,the inhibition included all bacterial isolates, with highest inhibition zone against Bacillus cereus ( $26 \mathrm{~mm}$ ), while Oregano did not exhibit clear antibacterial activity, Aeromonas hydrophila was the most resistant isolate. It was obvious from the results of effect of phenolic compounds on bacteria that no relationship between antibacterial activity and phenolic content and the inhibition may be due to other compounds.

\section{Key words: Oregano, Lemon palm, Antioxidant, Antibacterial, Phenolic content.}

\section{Introduction:}

For a long period of time plants have been a variable source of natural products for maintain human health. Studies have shown that many plants have chemical components and biological activities, therefore, could be used to treat various ailments. The most important of these bioactive constituents of plants are alkaloids, tannins, flavonoids and phenolic compounds [1]. Some plants from family labiatae such as Melissa officinalis and Oreganum vulgare have demonstrated high antioxidant activity. These plants often contain phenolic compounds and ascorbic acid [2]. The phenolic compounds reported to be present in those plants are hydroxycinnamic acid and flavones, mainly in the form of esters and glycosides [3]. Modern dietology recommends the use of several aromatic herbs (fresh or dry) to improve and enhance the flavor and aroma of the prepared mails [2]. Addition of these herbs in foods not only imparts flavor and pungent stimuli but also provides natural

* Institute of Genetic Engineering and Biotechnology for Post Graduate Studies/

University of Baghdad. 
antimicrobial and antioxidant compounds [4]. Phenolics belong to the very important group of plant antioxidants. The antioxidant effect depends mainly on the number and position of hydroxyl groups and the identity of the main substituents, but also on many other factors [5].

The aim of this study is evaluation the antioxidant capacity and antibacterial activity of selected herbs lemon palm and Oregano, using the ethanolic and purified phenolics extracts of these plants, and studies the relationship between the phenolic contents and these activities.

\section{Materials and Methods: Plant material :}

Fresh leaves of Oregano (Origanum vulgare) and Lemon balm (Mellisa officinalis ) were procured from markets of Baghdad city, Iraq. Authentication and identification of the plant was carried out by Dr. Ali AlMosawy, Department of Biology, College of Science, University of Baghdad.

\section{Sample preparation :}

The leaves of plants were cleaned and cut into small pieces, and then dried. The dried samples were then pulverized into fine powder in a grinder, which was then stored at $4{ }^{\circ} \mathrm{C}$ until use.

\section{Preparation of crude ethanolic extract:}

Air dried sample (20 gm) was soaked in $100 \mathrm{ml}$ of $95 \%$ ethanol, and shaken at $150 \mathrm{rpm}$ for $24 \mathrm{hr}$. at ambient temperature. The extract was Whatman ( filtered through filter paper No.1) which was impregnated with same solvent. The ethanol was concentrated to near dryness under using ${ }^{\circ} \mathrm{C}$ reduced pressure below 40 evaporator. The amount of the rotary concentrate extract was noted down. $\mathrm{ml} /$ The extracts were diluted to $20 \mathrm{mg}$ DMS) ( sulfoxide dimethyl \% with 10 solution and stored in air tight glass bottles in a refrigerator till further use

\section{Determination of total phenolic content:}

Total phenolic contents of all dry plants were determined using FolinCiocalteu assay as described by Attanassova et al. [7]. An alquot (1 ml ) of extracts or a standard solution of gallic acid (20, 40, 60, 80 and $100 \mathrm{mg}$ / L ) was added to a $25 \mathrm{ml}$ volumetric flask, containing $9 \mathrm{ml}$ of distilled deionised water ( dd $\mathrm{H} 2 \mathrm{O}$ ). A reagent blank using (dd H2O) was also prepared. One ml of Folin- Ciocalteu phenol reagent was added to the mixture and shaken. After 5 min., 10 $\mathrm{ml}$ of $7 \% \mathrm{Na} 2 \mathrm{CO} 3$ solution was added to the mixture. The solution was diluted to a $25 \mathrm{ml}$ with dd $\mathrm{H} 2 \mathrm{O}$ and mixed. After incubation for $90 \mathrm{~min}$. at room temperature, the absorbance against the prepared reagent blank was determined at $750 \mathrm{~nm}$ using spectrophotometer. The data for the total phenolic content of the plants were expressed as milligram of gallic acid equivalents (GAE) per gram dry mass (mg GAE / g dw). All samples analyzed in duplicated.

\section{Extraction and purification of phenolics [8]:}

A dried sample of leaves $(10 \mathrm{~g})$ extracted for $30 \mathrm{~min}$. by stirring at $4{ }^{\circ} \mathrm{C}$ with cold aqueous ethanol $(65 \% ; 200$ $\mathrm{ml})$ containing $0.5 \%$ sodium metabisulphite. The homogenate was filtered through four layers of cheesecloth, and the residue was then extracted with two additional portions (100 $\mathrm{ml}$ each) of the same extraction solution as described above. The combined filtrate was centrifuged at $7000 \mathrm{rpm}$ for $15 \mathrm{~min}$. at $4{ }^{\circ} \mathrm{C}$ and 
residue was discarded. Ethanol was removed from the supernatant under vacuum on a rotary evaporator at 35 ${ }^{\circ} \mathrm{C}$, and the mass is measured. Pigments were eliminated by two successive extractions with petroleum ether. After addition of $20 \%$ ammonium sulphate and $2 \%$ metaphosphoric acid to the aqueous phase, the compounds were extracted three times with ethyl acetate. The extracts were combined, evaporated and then dried under vacuum at $35{ }^{\circ} \mathrm{C}$. The residue was redissolved in methanol $(1 \mathrm{~g} / \mathrm{L})$ for analyses.

\section{Antioxidant extracts:}

Antioxidant activity of ethanolic, phenolic copounds extracts and standard were determined by FTC (Ferric Thiocyunate) method [9] as following :

For preparation of stock solutions, 10 $\mathrm{mg}$ of each extract was dissolved in 10 $\mathrm{ml}$ of distilled water. Then, the solution which contained $50 \mathrm{~g} / \mathrm{ml}$ of stock solutions and $\alpha$-tocopherol as standard sample $(50 \mathrm{~g} / \mathrm{ml})$ in $2.5 \mathrm{ml}$ of potassium phosphate buffer $(0.04 \mathrm{M}$, $\mathrm{pH} 7.0$ ), was added to $2.5 \mathrm{ml}$ of linoleic acid emulsion in potassium phosphate buffer (0.04 M, pH 7.0). The mixed solution $(5 \mathrm{ml})$ was incubated at $37{ }^{\circ} \mathrm{C}$ in flask. The peroxide level was determined by reading the absorbance at $500 \mathrm{~nm}$ in a spectrophotometer, after reaction with $\mathrm{FeCl}_{2}$ and thiocyanate at intervals during incubation. During the linoleic acid oxidation, peroxides are formed, which oxidize $\mathrm{Fe}^{+2}$ to $\mathrm{Fe}^{+3}$, The latter Ions form a complex with thiocyanate and this complex has a maximum absorbance at $500 \mathrm{~nm}$. Five ml linoleic acid emulsion: contained $17.5 \mu \mathrm{g}$ Tween $-20,15.5 \mu \mathrm{l}$ Linoleic acid and $0.04 \mathrm{M}$ potassium Phosphate buffer ( $\mathrm{pH}$ 7.0). On the other hand, the $5 \mathrm{ml}$ control was composed of $2.5 \mathrm{ml}$ linoliec acid emulsion and $2.5 \mathrm{ml} 0.04$
$\mathrm{M}$ potussium phosphate buffer $(\mathrm{pH}$ 7.0). This step was repeated every $5 \mathrm{hr}$. until the control reached its maximum absorbance value. Therefore, high absorbance indicates a high linoleic acid emulsion oxidation. Solution without added extracts was used as blank samples. All data on total antioxidant activity are the average of duplicate analyses. The percentage inhibition of lipid peroxidation in linoleic acid emulsion was calculated by following equation:

Inhibition of lipid peroxidation(\%)

$$
\begin{gathered}
=100-\left[\frac{\text { Asample }}{\text { Acontrol }} \times 100\right] \\
\text { Acontrol is the }
\end{gathered}
$$
absorbance of the control reaction.

Asample is the absorbance of the presence of the sample of (phenolic, aqueous or ethanolic extract or standard compound ( $\alpha$-tocopherol) .

\section{Microorganisms and media :}

The bacterial isolates $A$. hydrophila and S. typhi were isolated from patients with food poisoning (gastrointestinal infections). The bacteria were obtained, as clinical isolates, from $\mathrm{Al}-$ Yarmook Teaching Hospital, Baghdad, Iraq. While, $S$. aureus isolated from the salted white cheese and Bacillus cereus isolated from spoiled rice. Bacterial cultures were maintained on nutrient agar (NA) slops. Subcultures were made monthly and stored at $4 \mathrm{C}$.

\section{Culture preparation:}

A loopfull of $24 \mathrm{hr}$. surface growth on a NA slope of each bacterial isolate was transferred individually to $5 \mathrm{ml}$ of Brain heart infusion broth $(\mathrm{pH}$ 7.6) and incubated at $37^{\circ} \mathrm{C}$ for $24 \mathrm{hr}$. Then bacterial cells were collected by centrifugation at $3000 \mathrm{rpm}$ for $15 \mathrm{~min}$, 
washed twice and resuspended in $0.1 \%$ pepton water. Turbidity was adjusted to match that of as McFarland standard $\left(10^{8} \mathrm{CFU} / \mathrm{ml}\right)$. Then 1:10 dilution of the cell suspension was performed to give an inoculums concentration of $\left(10^{7} \mathrm{CFU} / \mathrm{ml}\right)$.

\section{Antibacterial activity test of extracts (in vitro) using agar diffusion assay method:}

$0.1 \mathrm{ml} \mathrm{ml}$ volume of the standard inoculums $\left(10{ }^{7} \mathrm{CFU} / \mathrm{ml}\right)$ of the test bacterial isolate was spread on Mueller Hinton Agar (MHA )with a sterile glass rod spreader and allowed to dry. Then $6 \mathrm{~mm}$. diameter wells were bored using cork borer in the MHA. Plant extracts $(1,5$ and $10 \mathrm{mg} / \mathrm{ml})$ were introduced into each well and allowed to stand for $1 \mathrm{hr}$. at room temperature to diffuse the plant extracts into medium before incubation at $37{ }^{\circ} \mathrm{C}$ for $24 \mathrm{hr}$. The inhibition zone diameter (IZD) was measured by transparent ruler to nearest $\mathrm{mm}$. Ciprofloxacin (10 $\mathrm{mg} / \mathrm{ml}$ ) (Oxoid) used as positive control inhibition zone with diameter less than 12 $\mathrm{mm}$. were considered as having no antibacterial activity, diameter between 12 and $16 \mathrm{~mm}$. were considered moderately active, and these with $16<\mathrm{mm}$. were considered highly active [10].

\section{Results and Discussion:}

Total phenolic contents of lemon balm (Melissa officinalis ) and oregano ( Oreganum vulgare) plants were showed in table 1.

Table (1.) Total phenolic contents of Mellisa officinalis and Oreganum vulgare plants

\begin{tabular}{|c|c|c|}
\hline Herb & Latin name & $\begin{array}{c}\text { Total phenolic } \\
\text { content (mg GAE } \\
\text { /gdw) }\end{array}$ \\
\hline $\begin{array}{c}\text { Lemon } \\
\text { balm }\end{array}$ & $\begin{array}{c}\text { Melissa } \\
\text { officinalis }\end{array}$ & 56.5 \\
\hline Oregano & $\begin{array}{c}\text { Origanum } \\
\text { vulgare }\end{array}$ & 27.5 \\
\hline
\end{tabular}

$\mathrm{GAE}=$ gallic acid equivalent.

The results showed that lemon balm had the highest total phenolic content $(56.5 \mathrm{mg} / \mathrm{g})$. While, oregano had the lowest content $(27.5 \mathrm{mg} / \mathrm{g})$. The total phenolic content in lemon balm was about more than two times that in oregano. In agreement with our results, lemon balm species had extremely high total phenolic contents, in contrast with other plants of family labiatae and green tea [11]. While the results of Chrpova et al. revealed that the total phenolic contents of oregano had extremely high total phenolic contents in comparison with Chinese green tea samples and other plants of family labiatae such as Sage, Basil and Hyssop [12].

Antioxidant activity of ethanolic extract, phenolic compounds extract and $\alpha$ - tocopherol of Melissa officinalis and Oreganum vulgare plants were summarized in figure 1 . 


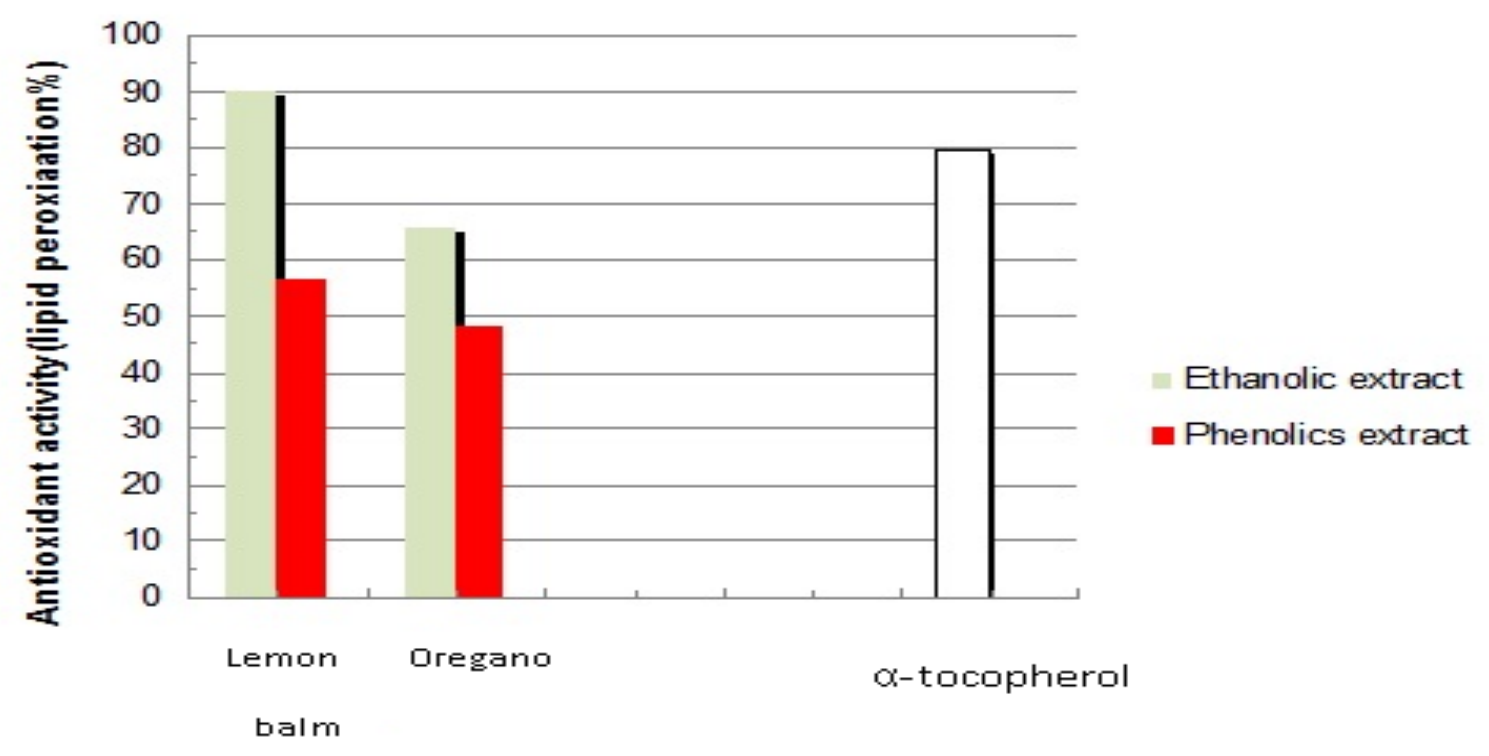

Plants

Fig(1.) Antioxidant activity of ethanolic extract, phenolic compounds extract and $\alpha$-tocopherol (standard) of lemon balm and oregano plants (after $40 \mathrm{hr}$ of incubation using FTC method).

After 40 hr.of incubation, ethanolic extract of lemon balm caused (90. $5 \%$ ) inhibition of lipid peroxidation of linoleic acid emulsion, this activity was greater than $\alpha$ tocopherol $(79.3 \%)$ and oregano $(66.5 \%)$. From the results of antioxidant activity of phenolic compounds extracts, it was found that the main source of antioxidant activity of these plants was due to phenolic compounds, such as with lemon palm when showed the highest phenolic content $(56.5 \mathrm{mg} / \mathrm{gm})$ as well as the highest antioxidant activity (90.5\%). The results suggested that the antioxidant ability could be mainly due to the presence of the phenolic compounds in the plant extract [13]. Medicinal plants are the main sources of natural antioxidants. Melissa officinalis belongs to the family of Lamiaceae, a large group of medicinal plants. M. officinalis is a perennial plant that grows in all over the Mediterranean region. The leaves of M. officinalis have been used in folk medicine especially in Turkey and Iran, for the treatment of some disease
[14]. In contrast of our results previous studies showed that the strong antioxidant activity of oregano by using different methods (DPPH radical scavenging method, ORAC assay and $B$-carotene bleaching method) in comparison with different plants [12], [15]. The results revealed strong correlation between the antioxidant activity and total phenolic compounds as the result of Herodes et al [16], whereas some authors found a poor correlation between phenolic content and the antioxidant activity [17].

Antibacterial activity of ethanolic extracts and phenolic compounds extracts of oregano and lemon balm against some of food poisoning bacteria were showed in table 2 . 
Table (2.) Antibacterial activity of ethanolic extracts and phenolic compounds extracts of oregano and lemon balm against some of food poisoning bacteria.

\begin{tabular}{|c|c|c|c|c|c|c|}
\hline \multirow[b]{3}{*}{$\begin{array}{l}\mathrm{N} \\
\mathrm{o}\end{array}$} & \multirow{3}{*}{$\begin{array}{l}\text { Pathogenic } \\
\text { bacteria }\end{array}$} & \multicolumn{5}{|c|}{ Diameter of inhibition zone $(\mathrm{mm})$. } \\
\hline & & \multirow{2}{*}{$\begin{array}{l}\text { Cip. } \\
\begin{array}{l}10 \\
\mathrm{mg} / \\
\mathrm{ml}\end{array}\end{array}$} & \multicolumn{2}{|c|}{ Lemon balm } & \multicolumn{2}{|l|}{ Oregano } \\
\hline & & & $\begin{array}{l}\text { Phenoli } \\
\text { c } \\
\text { extract } \\
\text { 100mg/ } \\
\text { ml }\end{array}$ & $\begin{array}{l}\text { Ethano } \\
\text { lic } \\
\text { extract } \\
100 \mathrm{mg} / \\
\text { ml }\end{array}$ & $\begin{array}{l}\text { Phenoli } \\
\text { c } \\
\text { extract } \\
\text { 100mg/ } \\
\text { ml }\end{array}$ & $\begin{array}{l}\text { Ethano } \\
\text { lic } \\
\text { extract } \\
100 \mathrm{mg} / \\
\text { ml }\end{array}$ \\
\hline 1 & $\begin{array}{l}\text { Aeromonas } \\
\text { hydrophila }\end{array}$ & 19 & N.I. & 13 & 7 & 8 \\
\hline 2 & $\begin{array}{l}\text { Salmonella } \\
\text { typhi }\end{array}$ & 16 & 11 & 18 & N.I. & 10 \\
\hline 3 & $\begin{array}{l}\text { Staphyloco } \\
\text { ccus aureus }\end{array}$ & 18 & 8 & 21 & 9 & 12 \\
\hline 4 & $\begin{array}{l}\text { Bacillus } \\
\text { cereus }\end{array}$ & 21 & 11 & 26 & 12 & 16 \\
\hline
\end{tabular}

It was found that ethanolic extract of lemon balm was more effective on all bacterial isolates with highest inhibition zone $(26 \mathrm{~mm})$ towards B. cereus, while Oregano which had high only exhibited moderate antibacterial activity, this suggested that there was no relationship between antibacterial activity and antioxidant activity. Also the results showed that no correlation between the phenolic contents and the antibacterial activity of plants. Many previous studies had reported that antibacterial activity was closely related to the concentration of phenolic compounds $[18,19]$.

A. hydrophila was more resistant than other bacteria. It has been suggested that high resistance to plant extracts in gram -negative bacteria is due to the outer membrane of their cell wall, acting as barrier to many substances including antibiotics (20). The antibacterial activity involved synergism between many constituents such as B-pinene, camphene and thujone [21]. The extracts of $M$. officinalis have been known to contain a number of antimicrobial compounds. Phytochemical screening of this plant has shown the presence of flavonoids (isoquercitrin, rhamnocitrin, luteolin, apigenin-7-O-glucoside) [22].

\section{References:}

1-Hedges, L. J. and Lister, C. E. 2007. Nutritional attributes of herbs, crop and food. Research Confidential Report, A report presented for Horticulfare New Zealand, pp. 42.

2-Yanishlieva, N.V., Marinova, E. and Pokorny, J. 2006. Natural antioxidants from herbs and spices. Eur. J. lipid Sci.. Technol. 108: 776-793.

3-Zandi, P. and Ahmadi, L. 2000. Antioxidant effect of plant extracts of labiatae family. J. Food Sci.Technol. 37:436-439.

4-Neras, M., Korhonen, A. R., Lindtrom, M. Turkki, P. and Korkeala, H. 2004. Antibacterial Efficiency of Finish Essential Oils against Pathogenic and Spoilage Bacteria. J. food prot.. 67 (1): 199202.

5-Dimtorios, B. 2006. Sources of natural phenolics antioxidants. Trends in Food Sci. and Technol. 17: 505-512.

6-Mingarro, D.M., Acero. N.,linares. F.,Pozuelo. J. M., Mera, A. C.and Peres, C. 2003. Biological activities from Catalen bignonioides walt. (Bignonieceae). J. Ethnopharmacol. 87 :163-167.

7-Atanassova, M., Georgieva, S. and Ivanchera, K. 2011. Total Phenolic and Total Flavonoid contents, Antioxidant Capacity and Biolgical Contaminants in Medicinal Herbs . J. University of Chem. Technol Metal. 46 (1):81-88.

8-Zhu, C., Deng, X. and Shi, F. 2008. Evaluation of the antioxidant activity of Chinese Hickory (Carya cathayensis ) Kernel ethanol extraction . Afr. J. Biotechnol. 7 (3) :2169-2173.

9-Gülcin, I., Mshrildudze, V., Gepdiremen, A. and Elias, R. 2006. 
Screening of Antioxidant and antiradical activity of monodesmosides and crude extract from Leontice smirnowii tuber. Phyomedicine .13 : 343-349.

10-Indu, M. N., Hatha A. A. M., Abirosh, C., Harcha, U. and Virekandan, G. 2006. Antimicrobial activity of a south -Indian species against serotypes of Escherichia coli ,Staphylococcus aureus, Listeria monocytogenes and Aeromonashydrophila. Brazil. J. Microbiol . 37 (2) :147-158.

11- Moraes, R. A., Oldoni, T.L.C. and Alencar, S.M. 2008. Antioxidant activity and phenolic coposition of herbal infusions consumed in Brazil.. Ceinc. Tecnol. Aliment. 6(1):41- 47.

12-Chrpova , D., Kourimska, L., Gordon, M.H., Hermanova, V. and Panek, J, 2010. Antioxidant Activity of Selected Phenols and Herbs Used in Diets for Medical Conditions . $J$. Food Sci. 28(4): 317-323.

13-Koksal, E. ,Bursal, E., and Gulcin, I. 2011 . Anioxidant activity of Melissa officinalis leaves. J Med plant res. .5 (2): 217-222.

14- Sadraei, H., Ghannadi, A., and Malekshahi, K. 2003. Relaxant effect of essential oil of Melissa officinalis and citral on rat ileum contractions. Fitoterapia. 74: 445452.

15-Alizadeh, A., Khosh-Khui, M., Jaridnia, K, Firazi, O.R. and Jokar, S.M. 2011. Chemical Composition of the Essential Oil, Total Phenolic content and Antioxidant Activity in Origanum majorana L.( Lamiaceae) Cultivated in Iran . Advances Environ. Biol. 5(8): 2326-2331 .
16- Herodez, S.S., Hadolin, M., Skerget, M., and Knez, Z. 2003. Solvent extraction study of antioxidants from Balm (Melissa officinalis L.) leaves. Food Chem. 80: 275-282.

17-Kalisic, T., Dragovic- Uzelac, V. and Meladen, M. 2006. Antioxidant Activity of Aqueous Tea Infusions Prepared from Oregano, Thyme and Wild Thyme. Food Technol. Biotechnol. 44(4): 485-492.

18-Shan, B., Cai , Y., Brooks , J.D. and Corke, H. 2007. The in vitro antibacterial activity of dietary spice and medicinal herb extracts. Inter.J. Food microbiol.. 117: 112-119.

19-Jimoh, F.O. , Adedapo, A. A. and Afolagan, A. J. 2011. Comparison of the Nutritive Value, Antioxidant and Antibacterial Activities of Sonchus asper and Sonchus oleraceus .Rec. Nat. Prod. 5(1):2942.

20-Marino, M., Berrsami, C. and Comi, G, 2011. Impedance measurements to study the antimicrobial avtivity of essential oils from Lamiaceae and Composital. Int. J. Food Microbiol. 67: 187-195.

21-Mitic -Culafic, D., Vukovic-Gacic, B. and Simic, D. 2005. Comparative Study on the Antibacterial Activity of Volatiles from Sage (Salvia officinalis L.) Arch. Biol. Sci. Belgrade .57(3):173-178.

22- Patora, J. and Klimek, B. 2002 Flavonoids from lemon balm (Melissa officinalis L., Lamiaceae). Acta Pol. Pharm . 59: 139-143. 


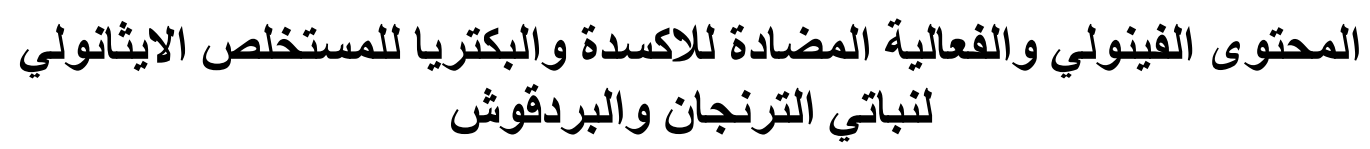

درست الفعالية المضادة للاكسدة للمستخلص الايثانولي ومستخلص المركبات الفينولية لنباتي الترنجان

و البردقوش و فعاليتها المضادة اتجاه بعض بكتريا التسمم الغذائي (typhi , Staphylococcus aureus و (Aeromonas hydrophila, Bacillus cereus ， Salmonell

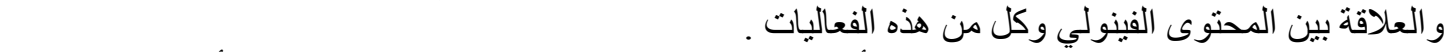

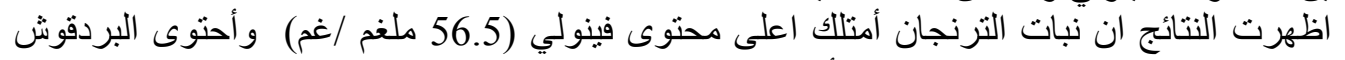

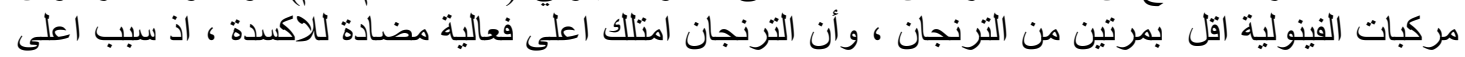

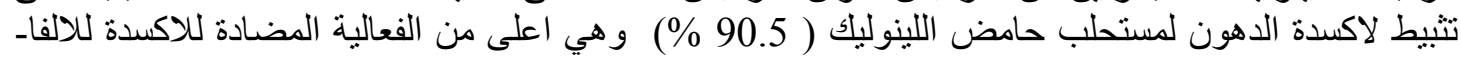

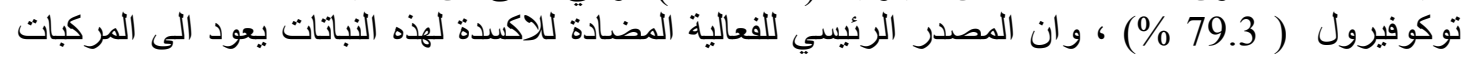

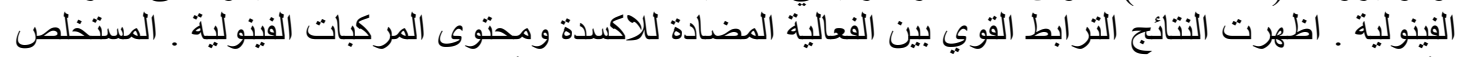

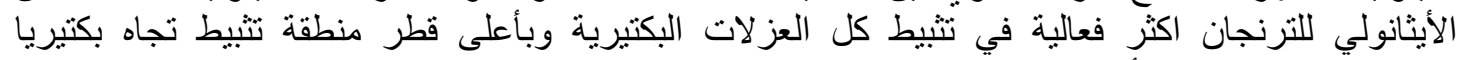
A.hydrophila B.cereus

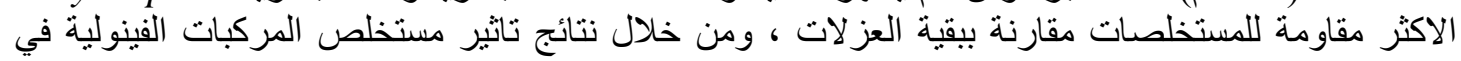

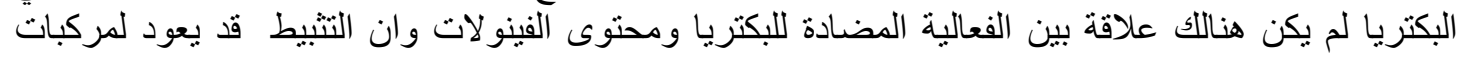

